\title{
Biotic stress (insect) of aonla (Emblica officinalis) in arid region of India: a review
}

\author{
SM Haldhar, Chet Ram \& D Singh
}

Journal of Agriculture and Ecology

Volume-7 (June, 2019)

ISSN: 2456-9410

\section{Journal of Agriculture}

and Ecology

ISSN: 2456-9410

Volume: 7

Journal of Agriculture and Ecology (2019) 7: 16-26 http://doi.org/10.53911/JAE.2019.7102 


\title{
Biotic stress (insect) of aonla (Emblica officinalis) in arid region of India: a review
}

\author{
SM Haldhar $\not$, Chet Ram \& D Singh \\ ICAR-Central Institute for Arid Horticulture, Sri Ganganagar Highway, Beechwal Industrial Area, \\ Bikaner (Rajasthan)-334006, India
}

Corresponding author: SM Haldhar, E-mail: haldhar80@gmail.com

\begin{tabular}{|c|c|}
\hline Artic & Abstract \\
\hline & $\begin{array}{l}\text { ndian gooseberry, Emblica officinalis popularly also known as Aonla, } \\
\text { mla, amrit phal is found attacked various number of insect-pests causing }\end{array}$ \\
\hline & nsiderable damage. In India, the major insect-pests reported from aonla \\
\hline bruary & are shoot gall maker Betousa stylophora; leaf roller, Caloptilia \\
\hline ril & (Garcillaria) acidula; hairy caterpillar, Selepa celtis; bark eating \\
\hline & osticha) \\
\hline & ziziphy; bag worm, Zeuzera sp.; fruit borer, Meridarchis sp.; \\
\hline & pomegranate butter fly, Deudorix isocrates; fruit suckin \\
\hline $\begin{array}{l}\text { Key Words: Biotic } \\
\text { stress, insects, aonla, }\end{array}$ & $\begin{array}{l}\text { janata; fruit midge, Clinodiplosis sp.; cow bug, Tricentrus congestus; } \\
\text { plant hopper, Seliza truncate; spherical mealy bug, Nipaecoccus viridis; } \\
\text { weevil, Myllocerus discolour; termite, Odontotermes obesus; leaf miner, } \\
\text { Phyllocnistis citrella and hairy caterpillars, Euproctis fraterna. }\end{array}$ \\
\hline
\end{tabular}

Copyright (C2019 Haldhar et al., This is an open access article published under the terms of the Creative Commons Attribution License, which permits unrestricted use, distribution, and reproduction in any medium, provided the original work is properly cited.

Preferred citation: Haldhar SM, Chet Ram \& Singh D. 2019. Biotic stress (insect) of aonla (Emblica officinalis) in arid region of India: a review. Journal of Agriculture and Ecology, 7: 16-26; http://doi.org/10.53911/JAE.2019.7102.

\section{Introduction}

Aonla (Emblica officinalis Gaertn.) is used for medicinal and therapeutic properties from the ancient time in India and considered wonder fruit for health conscious population. The origin of aonla plant is tropical Southeast Asia (Central or Southern India), Pakistan, Sri Lanka, Malaya, Bangladesh, Southern China and to Mascarene Islands. According to Hindu mythology, one-day meal is arranged beneath aonla tree during October-November when trees are laden with mature fruits. Hindu literature also prescribes that if ripe fruits of aonla are eaten for forty days in the morning after fast, it restores health and vitality known as Kaya Kalpa (Benthal 1946; Haldhar et al. 2016b). The aonla owing to hardy nature, suitability to various wastelands is one of the oldest Indian fruit. The aonla fruit has aroused good deal of interest among the scientific workers because it is one of the richest sources of the vitamin $\mathrm{C}$ and possess high productivity unit area (15-20\% ha), nutritive and therapeutic value, aonla has become an important fruit. It contains 500-700mg ascorbic acid per $100 \mathrm{~g}$ of pulp. Aonla fruit is acrid, cooling, refrigerant, diuretic and 
laxative. Dried fruits have been reported to be useful in hemorrhages, diarrhea, dysentery, anemia, jaundice, dyspepsia and cough (Samadia \& Haldhar 2017).

Aonla was supposed to be free from major insect-pests menace but with lapse of time and intensification of its cultivation, a number of insects have started feeding and infecting at various stages and causing considerable damage (Haldhar et al. 2013; Haldhar \& Deshwal 2017a). A variety of insect-pests, like shoot gall maker, Betousa stylophora; bark eating caterpillar, Inderbela quardinatata and aphids, Schoutedenia emblica recorded as major pests, whereas, pomegranate butter fly, Virchola Isocrates; leaf rolling caterpillar, Gacillaria acidula; cow bug, Tricentrus congestus; hairy caterpillar, Selepa celtis and termite, Odentotermis obesus recorded as minor pests on this plant (Choudhary et al. 2005; Haldhar et al. 2016a). Jhala et al. (2003) and Haldhar et al. (2017b) reported occurrence of fruit borer, midge and leaf cutting weevil for the first time in northern and western India. The major insect-pests of aonla are reviewed and discussed in this manuscript.

\section{Shoot gall maker, Hypolamprus stylophora (Swinhoe) (=Betousa stylophora)}

The gall disease of 'aonla' occurs throughout India, Sri Lanka, Myanmar, Bangladesh, China (Hong Kong) and Java. Though known to occur widely in India, but it is minor sporadic pest in most of the areas, its occurrence, excepting a few places where it causes considerable economic losses. It is a specific pest of 'aonla' and it is not known to attack any other host so far.

This pest attacks aonla nurseries and orchards in rainy season in arid region of
Rajasthan. The newly hatched caterpillar bores into twig which gradually swells up at the bore site and in due course develops into a typical gall housing the larva. The newly formed galls are small but proportionally much longer than broad. The gall size increases proportionally with larval size and development and becomes almost the maximum by end of November. The mature galls measure 20-26 mm in length and 10-15 $\mathrm{mm}$ across. Inside the gall, the larva feeds on the succulent woody tissues and pushes out reddish frass and excreta through a small hole at one end, kept guarded by a mesh work of silken threads. The gall is a hollow swelling/localized tumescence of the tender shoot, irregular, roughly, spindles shaped and resembling 'Snake charmer's flute'. In the beginning of the infestation terminal shoots swell, which increases in size with the passage of time. Full size galls can be seen in the month of October-November. The twig infestation was recorded maximum (40\%) in variety NA-10 followed by Chakaiya (34\%) and the minimum twig infestation was recorded (13.5\%) in seedling (Desi). This pest attack may result in stunted growth of the trees, affecting flowering and fruiting pattern. The climatic factors play substantially role in the biology of any pest, of which temperature is the crucial abiotic factor influencing the life economy of any organism. It is rather difficult to find a direct relationship between any single climatic factor and pest activity because the impact of weather elements of pest remained usually confounded (Reddy et al. 2001). Malvia (2006) found that weather factors had no influence on the incidence of shoot gall maker in aonla. Whereas, Mahor (2007) found 
that the relative humidity had no influence on the incidence of the pests but the incidence of pest was found positively correlated with the average temperature.

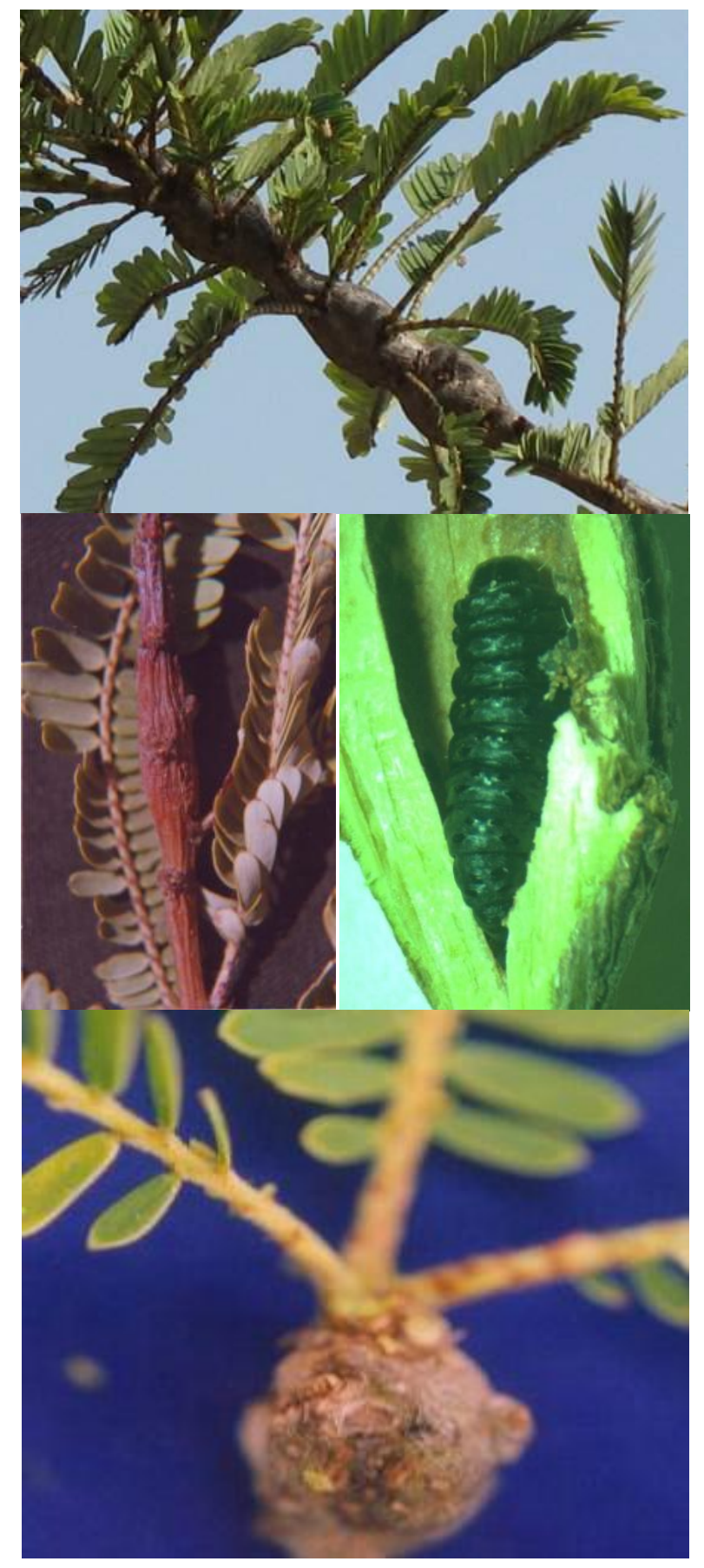

The eggs are deposited singly on the surface of twigs and shoots of new flush in June-July, preferably near or at the growing tips of branches. The newly hatched caterpillar bores into twig which gradually swells up at the bore site and in due course develops into a typical gall which house the larva. The newly formed galls are small but proportionally much longer than broad. The gall size increases proportionally with larval size and development and becomes almost the maximum by end of November. The larval activity slows down during winter but the larva resume feeding with the onset of spring season and becomes full grown by AprilMay. When the galls were opened up, black coloured sluggish larvae were observed inside them. Single gall was observed to host single larva in it, which slowly completes its life cycle inside the gall. The full grown caterpillar comes out of the gall by enlarging the entrance hole and pupates on the twig/ shoots among the new leaflets. The larva prepares a barrel shaped pupal chamber by joining 5 leaflets in a characteristic manner, by means of silken threads, deposits of chewed and regurgitated leaf tissues; which provides strength to the pupal shelter. The full grown cylindrical caterpillar tapering gently at both ends with grey head and jet-black thorax and abdomen, measures 10-11 mm in length and $2.25-2.50 \mathrm{~mm}$ in width The larva takes about 2 days to prepare the chamber well closed on all sides, and later prepares a cocoon within the chamber. In the absence of chamber larva fails to pupate. The beautiful red pupa measures about $6 \mathrm{~mm}$ in length and $2.75 \mathrm{~mm}$ in breadth. The pupal stage lasts for 8-10 days during May-June. The moth emerges through 
the anterior end of the pupal chamber and is short lived. The larval development is fairly slow and only a single generation is completed in a year. The window-winged moths are rarely encountered in the orchards. Meshram et al. (2003) found that the pest started its activity from the month of June by laying the eggs on the leaflets. The eggs hatched within a week and tiny caterpillars bored into twig or shoot and reach the pith during JulySeptember. The full grown caterpillar nearly $11 \times 2 \mathrm{~mm}$ and the gall size $23 \times 10 \mathrm{~mm}$ were observed in the month of October to March. The caterpillar came out of the gall in the month of October to March. The caterpillar comes out of the gall in the beginning of summer (April-May) and pupated in the chamber about two days the pupal period last for 8-10 days in the month of May-June.

\section{Pomegranate butterfly, Deudorix Isocrates (Fab.) (=Virachola isocrates)}

The butter fly is found in South and South-East Asia. This pest is found all over India and adjoining countries feeding on one or other host fruits. Its common names include common pomegranate or anar butterfly. The larva of this pest bores the fruit and feeds on seeds, making this portion hollow from inside. Affected fruits are deformed at the point of entry of larvae. Frass have been seen exuding out of the borer hole. The entrance hole was spotted out by the presence of offensive smelling excreta which gets stuck around the hole on the fruit surface. The affected fruits are subject to bacterial and fungal infections leading to fruit rots. Such fruits weaken, rot and the fell down before maturation. In case of severe attack, it may cause considerable loss.
A single caterpillar damages several fruits, shifting from one fruit to another adjoining one during the course of its development. Usually only one larva feeds inside a single fruit. In case of severe infestation, the borer has been reported damaging about 40-70 per cent fruits of aonla during rainy season in some areas (Atwal 1976; Khan 2016).

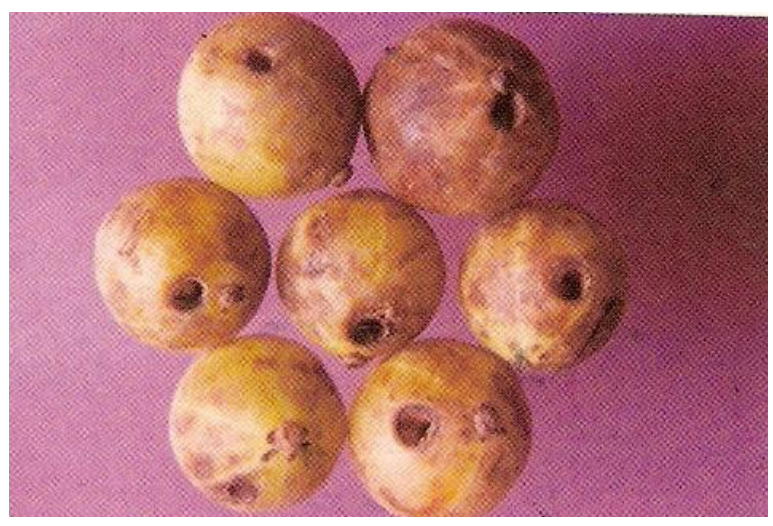

The female butterfly lays shiny white, oval shaped eggs singly on fruits and various other parts of bearing shoots during day. The eggs hatch in a week to 10 days. The newly hatched larvae do not feed on leaflets, but immediately bore into the developing fruits and feed for 18-47 days depending upon the season. Pupation takes place outside the fruit in a silken web, generally on the base of fruit, often on stem or branches or even among the fallen fruits. The pupal period varies from 7 34 days during different months. The butterflies are medium sized and measure 40$50 \mathrm{~mm}$ across the wings; the males are slightly smaller than the females. The butterflies are glossy-bluish-violet (males) or brownish violet (females) in colour, with an orange patch on the forewings which is conspicuous in females. The adult is live for about a week. Kumar et al. 2017 revealed that gravid female lays shiny white eggs singly on the calyx of 
flowers or on young fruits. The incubation, larval, prepupal and pupal periods were $7.15 \pm$ $0.10,32.9 \pm 2.38,4.35 \pm 0.12$ and $10.25 \pm$ 0.10 days respectively. The adult longevity of male and female was $8.26 \pm 0.14$ and $10.28 \pm$ 0.20 days respectively. Sexual dimorphism was observed in adults. D. isocrates took about 52-75 days with on an average $63.92 \pm$ 2.87 days to complete life cycle from oviposition to adult emergence on pomegranate.
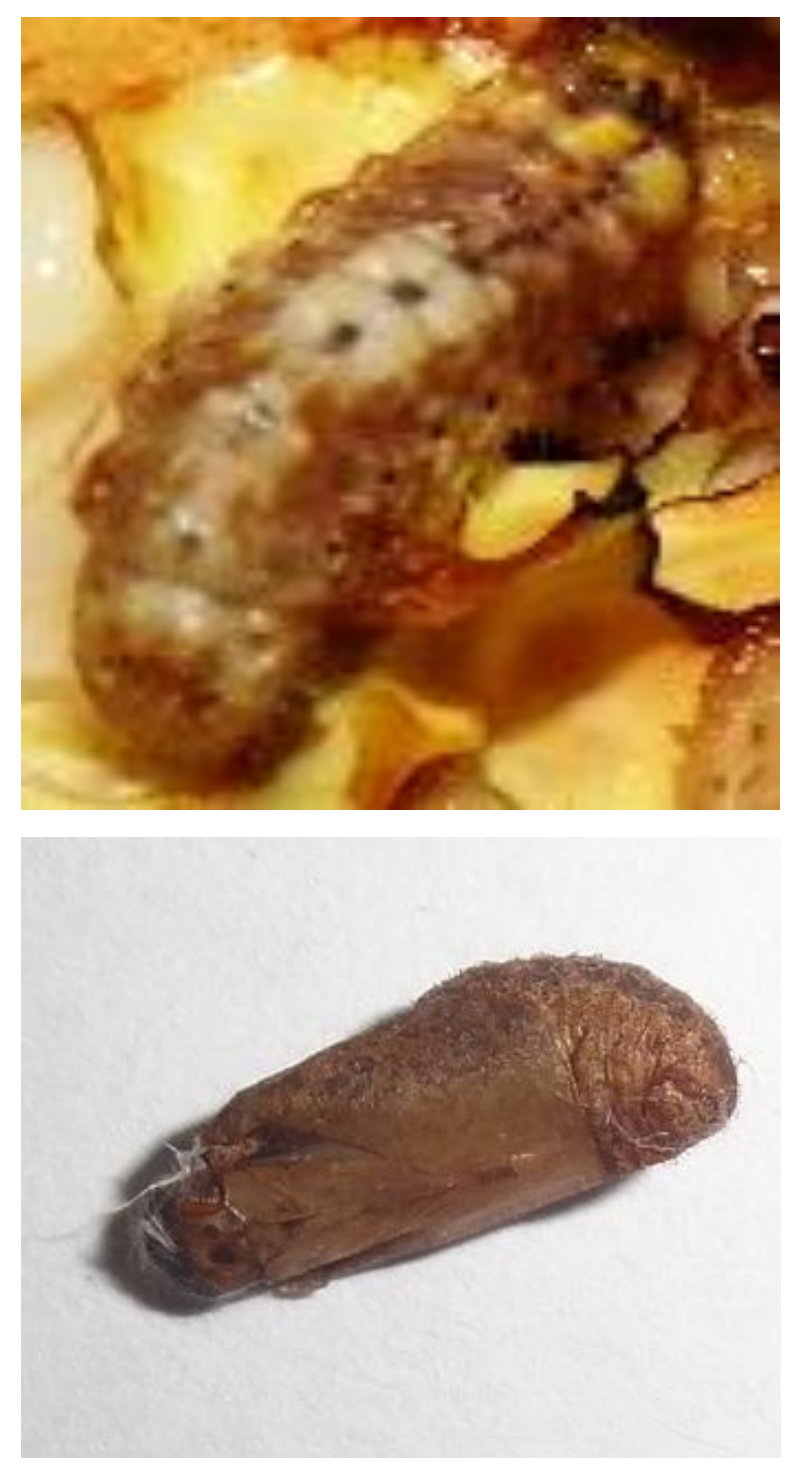

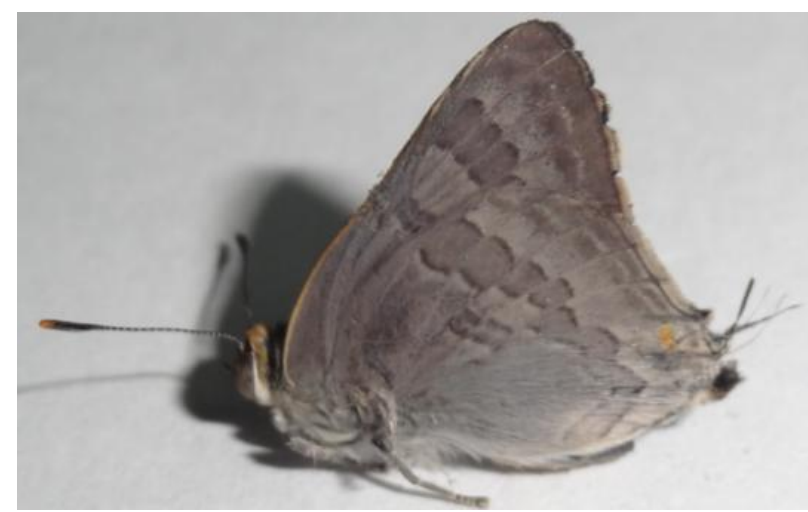

\section{Bark eating caterpillar, Indarbela quadrinotata (Walker)}

The pest is widely distributed throughout the country, infesting a number of fruits, ornamentals and forest trees. Generally, incidence of this pest is more common in neglected and poorly managed orchards. Thick, ribbon like, silken webs are seen running on the bark of the main stem be seen on a tree, one caterpillar or pupa occupying each hole. A severe infestation may result in the death of the attacked stem but not of the main trunk. There may be interference with the translocation of cell sap and thus arrestation of growth of the tree is noticed with the resultant reduction in its fruiting capacity. Sen-Shrma (1987) reported that aonla was severely attacked by $I$. quardrionotata. They reported that the high incidence of bark-eating caterpillar was an indication of unhealthy condition of crop. Choudhary et al. 2005 conducted studies on field performance of some varieties of aonla against bark eating caterpillar, I. quadrinotata at Khandwa (M.P.) and reported varieties local and Kanchan to be less susceptible and N.A.-10, Krishna, N.A.-7 to be relatively more susceptible on the basis of number of holes due to bark eating caterpillar. 


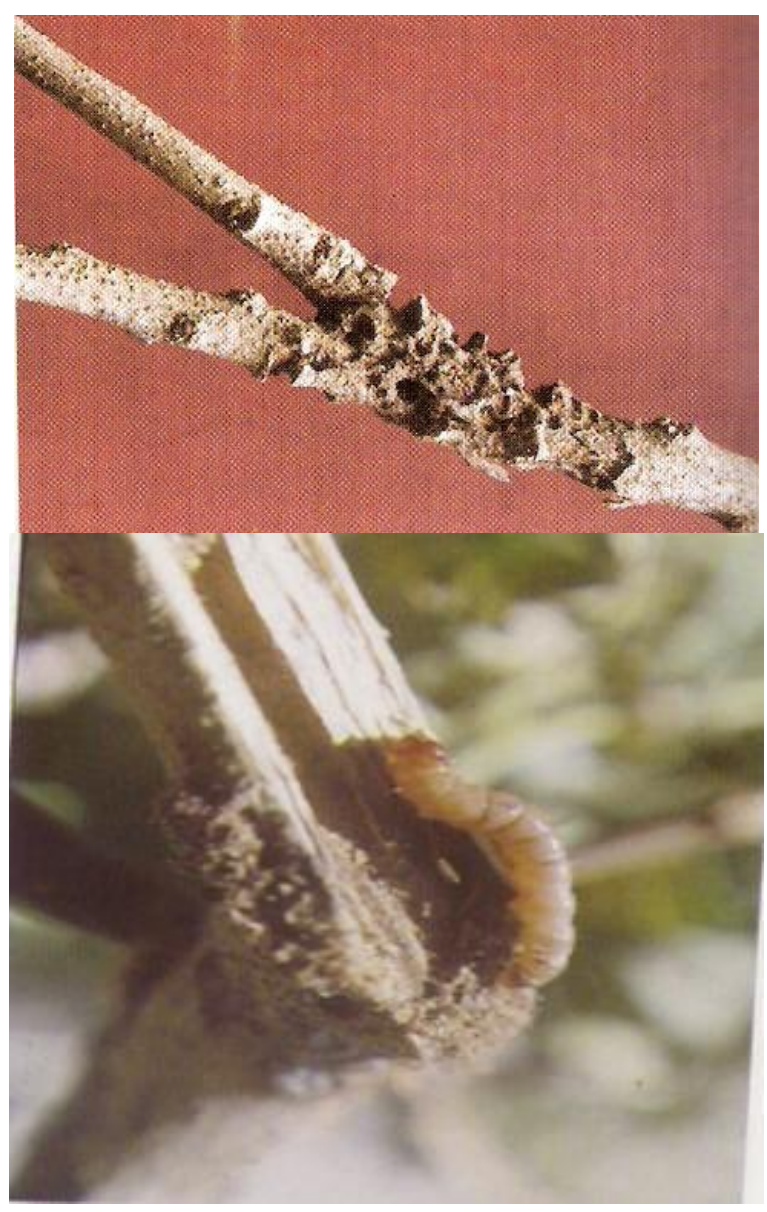

The female laid eggs in clusters of 1525 each, under the loose bark of the trees. As many as 2000 eggs may be laid by a single female. The eggs hatch in 8-10 days and the freshly hatched larvae nibble at the bark and after 2-3 days bore inside. The larvae have the habit of making webs along the feeding galleries and above the holes where they bore deeper into the wood. The galleries and the webs above them have a zig- zag shape and contain wooden frass and excreta. The larvae take as many as 9-11 months inside. The pupal stage lasts 3-4 weeks. The moths emerge in summer and they are short lived. Only one generation completed in a year. Satyanarayana $\&$ Arunakumara (2016) reported that the eggs were 0.67 to $0.73 \mathrm{~mm}$ long and 0.42 to 0.46 mm wide and they hatched in 7 to 11 days. Full grown larvae were 37 to $43 \mathrm{~mm}$ long and 6 to $8 \mathrm{~mm}$ wide. Larval duration was 274 to 298 days. Pupae were 11 to $15 \mathrm{~mm}$ long and 4 to $6 \mathrm{~mm}$ wide and the pupal period was 21 to 26 days. Male adult had wing span of 11 to 13 mm length and width of 20 to $24 \mathrm{~mm}$ and female adult had wing span of 12 to $14 \mathrm{~mm}$ and width of 25 to $27 \mathrm{~mm}$.

\section{Mealy bug, Nipaecoccus vastatar Newstead (Nipaecoccus viridis)}

The mealy bug, $N$. vastatar is distributed in Oriental, Palearctic and Ethiopian regions and is a destructive pest of various domesticated plants. Mealybugs once considered as minor pests have assumed the status of major status due to their polyphagous nature coupled with high reproductive capacity with short life cycle which is more favoured due to prolonged drought and quick dispersal through wind, seeds and planting materials. High population of nymphs results in drying and dropping of leaves and flowers which affect growth of the tree, flowering and fruiting. The attacked new shoots are found bending and twisting with yellowing of leaves (Sharaf 1997). In case of plants with severe infestation, twigs become leafless and dry. Excessive excretion of honey dew is noticed. Flowers dry up and drop. Among the nymphs, female adults are easily distinguished. Eggs are laid in ovisac formed by the females. A female bug lays hundreds of eggs. Nymphs get settled on plant parts (leaf, shoot and inflorescence) and suck the sap. They attain maturity within 15 to 20 days (Devi \& Rajasekaran 2011). 


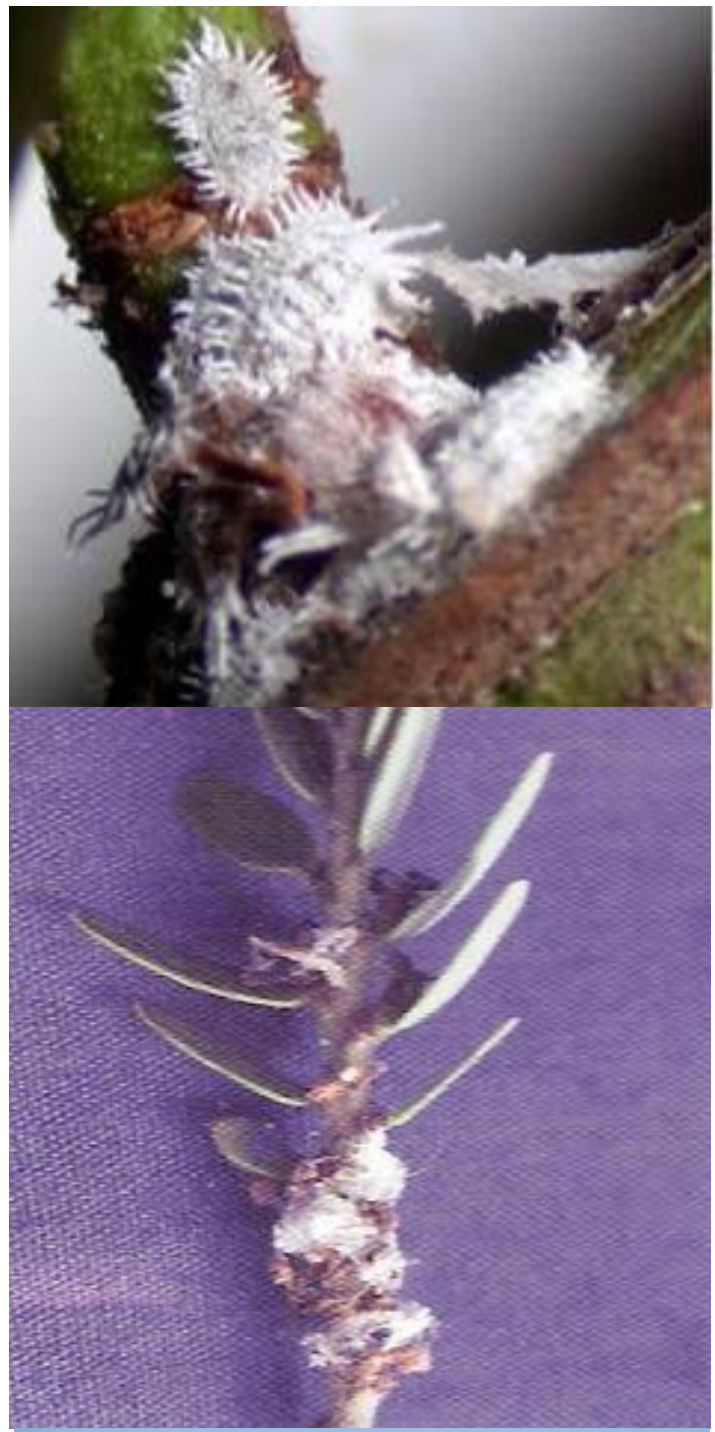

\section{Aonla aphids, Schoutedonia (=Cerciaphis) emblica (Patel \& Kulkarny)}

The incidence of this pest is mainly seen from July to October with the peak period in September (Devi \& Rajasekaran 2011). The new shoots are infested at growing points. The nymphs and adult females suck the sap. Heavy attack of this pest affects the growth and vigour of the tree and ultimately affecting the flowering and fruiting. The infested leaves turn yellow and dry up. Infested shoots appear bended and twisted at the growing points. Presence of ants also indicates the infestation of aphids. The new shoots are infested at growing points. The nymphs and adult females suck the sap. Heavy attack affects the growth and vigour of the tree, ultimately affecting the flowering and fruiting. Aphids were observed to congregate on the new flush at the growing points of aonla. The infested leaflets turned yellow and dried up (Chandha 2001).
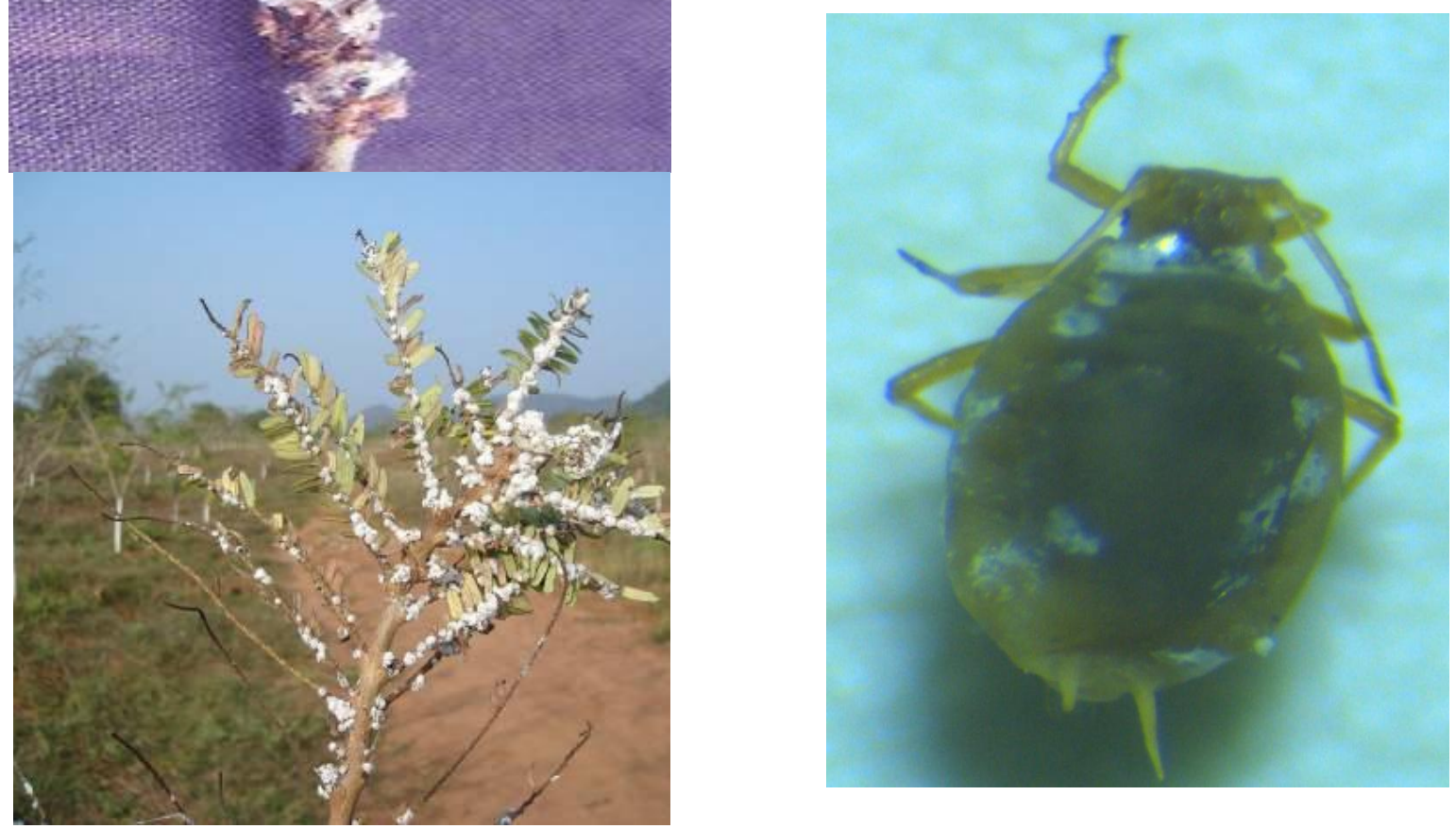


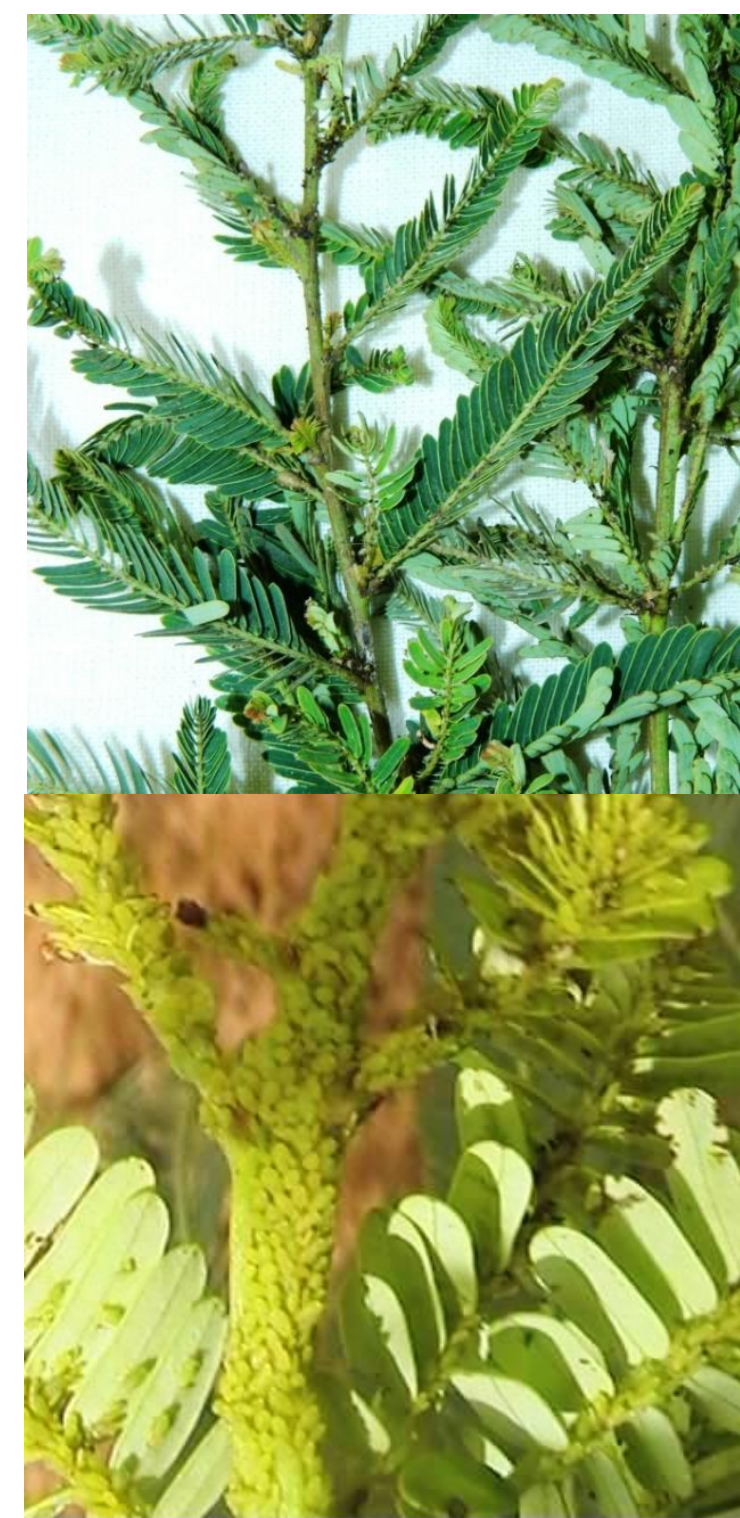

The aphid was exclusively viviparous and parthenogenetic. The duration of first, second and third nymphal instars were 3-4; 23and 3.0 days respectively with a total nymphal duration was 8.9 days. The average length and breadth of adult aphid was 1.60 $\mathrm{mm}$ and $0.79 \mathrm{~mm}$ respectively. The adult aphid lived up to 12-13 days and single adult aphid produced 26.0 to 30.0 nymphs during the reproductive period.

\section{Leaf rollers, Caloptilia (Garcillaria) acidula (Meyrick)}

The incidence of $C$. acidula remained active from May to February. Initially, the incidence is very low but then gradually increased and reached to its peak during August. Later on, it showed decreasing trend and disappeared from the aonla orchards during the end of February (Rani et al. 2006; Masarrat Haseeb 2005). Jhala et al. (2003) observed the activity of leaf roller during June to September. Small yellowish-white tiny larvae of leaf roller initially mined the leaflets but advanced instar larvae rolled the leaflets. It was found feeding on chlorophyll content by scrapping the rolled leaves. The damaged leaflets fall down and only midrib remained on the twig. In case of heavy incidence, leaves dry and drop leading to drying of twigs. Webbing of leaves may identify the infestation; they are withering and dropping. The purplish brown tiny moth of pest lays eggs singly on underside of new leaves and these hatches in 2-3 days. On hatching young apodous caterpillars make zig-zag mines on the ventral surface of tender leaves and feed within the mine singly. The full grown larva pupates in a silken cocoon on the undersurface of the leaf and the pupal duration varies from 9-13 days. The adults are small delicate moths with narrow long fringed wings and can be recognized by their peculiar habit of resting with fore parts of the body upraised. 


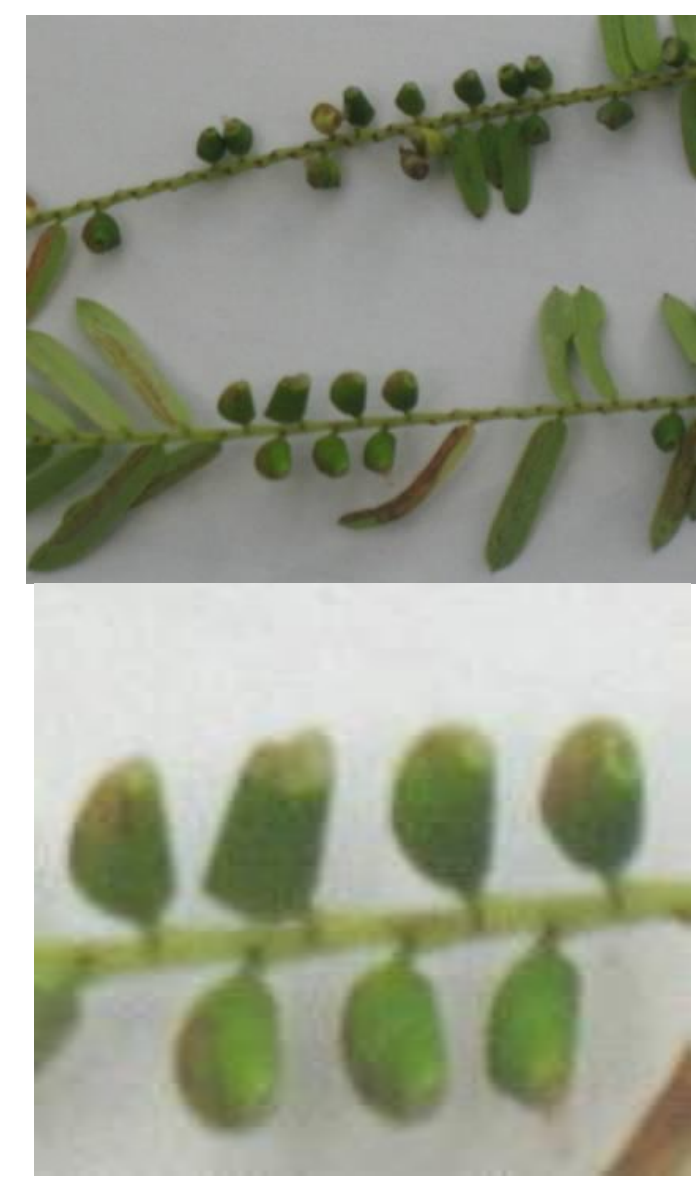

Termites, Odontotermes obesus R.

Incidence of pest worked out indicated that incidence of termite revealed especially during latter part of summer and early part of monsoon (April to July) before rainy days, being maximum $(7.00 \%$ tree damage) during second fortnight of June. The damage caused by this pest is noticed from August to December (Singh 1993). But its activity again commenced from first fortnight of January at lower level, gradually increases in subsequent months and reaches to a peak during June. The infestation of termites is more in sandy loam soils. They inflict more serious damages in the unirrigated areas. Workers of termites feed on the roots and stem parts of the plants. This results in drying of the plants. Other forms do not cause any direct damage to the crop. Soon after, first monsoon showers, the sexual forms leave their colony for nuptial flight during evening. After a short flight mating takes place, they shed their wings and the queen and king settle down in the soil. The female burrows in the soil lay eggs and establish new colony. The queen gradually grows in size and start egg laying very rapidly at the rate of one egg per second or 70,000 to 80,000 eggs in 24 hours. It lives for 5 to 10 years. It can live for several years also. There is only one queen in a colony. Incubation period is one week in summer and within 6 months larvae develop to form soldiers or workers. The reproductive castes when produced mature in 1-2 years.

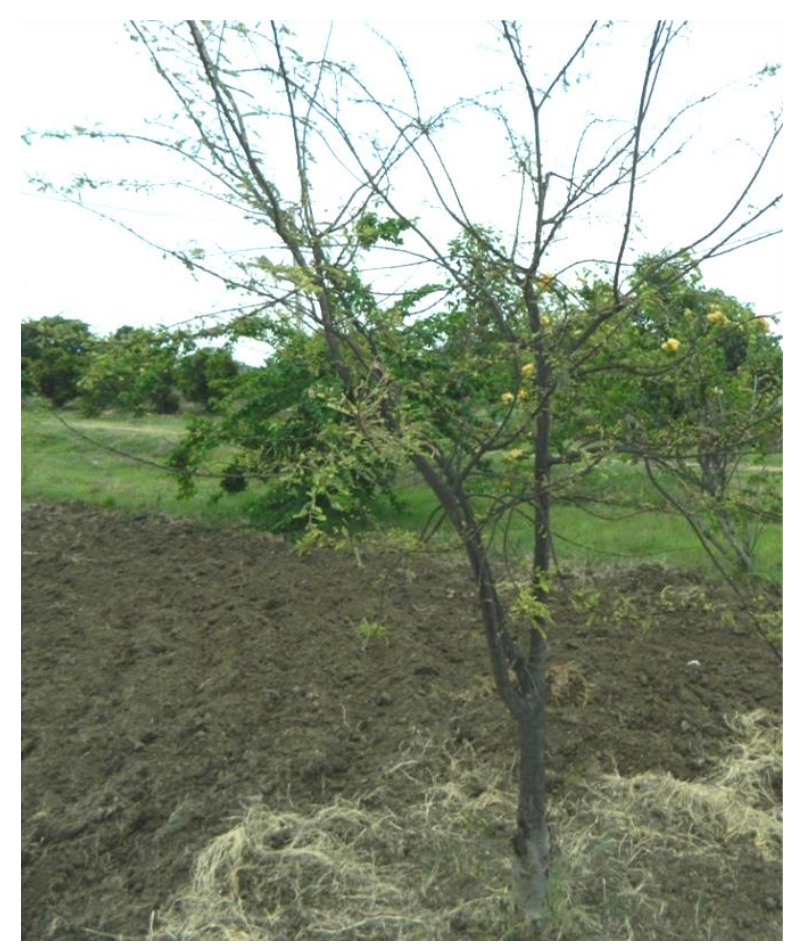




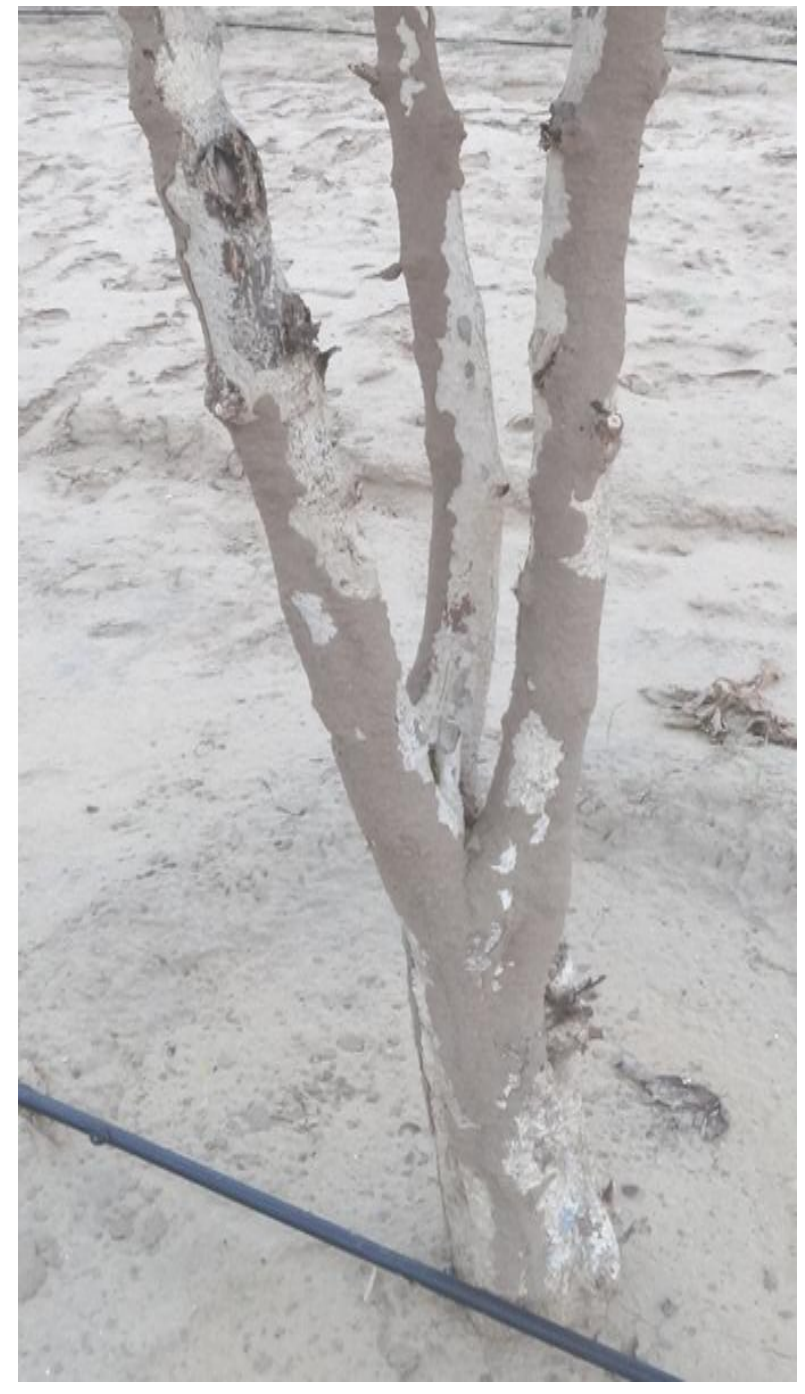

\section{Acknowledgments}

The authors are thankful to Director, ICAR-Central Institute for Arid Horticulture, Bikaner, India, for providing facilities and advice required for experimentation, and to $\mathrm{R}$. Swaminathan, Professor, Department of Entomology, MPUAT, Udaipur, India for critical discussion and suggestions.

\section{References}

Atwal AS. 1976. Agricultural pests of India and South-East Asia. Kalyani Publishers, Ludhiana. pp 529.
Benthal AP. 1946. Trees of Calcutta and its Neighbourhood. Thacker Spink \& Co. Ltd., Calcutta.

Chandha KL. 2001. Hand book of Horticulture. Directorate of information and publications of Agriculture. Indian Council of Agricultural Research Krishi Anusandhan Bhawan, Pusa, New Delhi pp- 1019.

Choudhary RK, Garg VK, Asathi KP \& Patel Y. 2005. Field performance of some cultivars of Indian gooseberry (Emblica officinalis Gaerth) against bark eating caterpillar, Indarbela quadrinotata (Walker). Indian Forester, 131(1): 131133.

Devi SJ \& Rajasekaran B. 2011. Biology and morphology of Aonla aphid, Schoutedonia emblica. Madras Agriculture Journal, 98 (7-9): 277-278.

Haldhar SM \& Deshwal HL. 2017. Fundamentals of Agriculture Entomology. New Vishal publication, 1: 1-452.

Haldhar SM, Deshwal HL, Jat GC, Berwal MK \& Singh D. 2016a. Pest scenario of ber (Ziziphus mauritianaLam.) in arid regions of Rajasthan: a review. Journal of Agriculture and Ecology 1: 10-21.

Haldhar SM, Jat GC, Acharyya P, Samadia DK, Singh D \& Meena SR. 2016b. Integrated pest management and optimal use of pesticides in arid fruit and vegetable crops. In Jatav MK, Acharyya P, Krishna H, Singh D. Samadia DK \& Sharma BD (Eds.), Good Management Practices for Horticultural Crops. New India Publishing Agency, New Delhi110034, 355-368.

Haldhar SM, Jat GC, Deshwal HL, Gora JS \& Singh D. 2017b. Insect pest and disease management in organic farming. In B Gangwar and NK Jat (Eds), Towards Organic Agriculture. Today \& 
Tomorrow's Publishers, New Delhi, 359-390.

Haldhar SM, Maheshwari SK \& Muralidharan CM . 2017a. Pest status of date palm (Phoenix dactylifera) in arid regions of India: a review. Journal of Agriculture and Ecology, 3: 1-11.

Haldhar SM, Sharma SK, Bhargava R, Singh RS, Sharma BD \& Singh D. 2013. Insect pests of arid fruit crops: practical manual for field identification and damage symptoms. CIAH/Tech./Pub, 1-53.

Jhala RC, Bharpoda TM, Patel MG, Patel VB \& Patel JR. 2003. Survey on insect pest and their natural enemies occurring in aonla orchard under middle Gujarat condition. Paper presented in Nat. Seminar on production and utilization of aonla, organized by All India Aonla Growers Association, Salem, Tamil Nadu, India.

Khan MMH. 2016. Biology and management of fruit borer, Virachola isocrates (Fab.) infesting Guava. Bangladesh Journal of Agricultural Research, 41(1): 41-51.

Kumar KP, Jayanthi PDK, Naik SO, Verghese A \& Chakravarthy AK. 2017. Biology of anar butterfly, Deudorix isocrates (Fab.) (Lycaenidae: Lepidoptera) on pomegranate, Punica granatum L., International Journal of Pure Applied Bioscience, 5(1): 498-503.

Mahor B. 2007. Studies on non-hemipteron insect pests of aonla, Phyllanthus emblica Linneus.), M.Sc. (Ag.) Thesis (Unpublished), JNKVV, College of Agriculture, Gwalior (M.P.).

Malvia TN. 2006. Studies on insect pest complex of aonla. M.Sc. (Ag.) Thesis (Unpublished), College of Agriculture, JNKVV, Jabalpur (M.P.).

Masarrat Haseeb. 2005. Insect pests of aonla and their management. In: Amla in India, S. S. Mehta and H. P. Singh
(Eds.), Aonla Growers Association, Salem. p. 128-138.

Meshram PB, Patra AK \& Garg VK. 2003. Seasonal history and chemical control of gall forming insect Betousa stylophora Swinhoe, on Emblica officinalis Gaerth. Indian Forester, 129 (10): 1249-1256.

Rani BU, Kalyanasundaram M \& Suresh K. 2006. Major sucking pests of aonla and their management. Indian Journal of Arecanut, Spices and Medicinal Plants, 8: 108-110.

Reddy CN, Singh Y \& Singh VS. 2001. Indian Journal of Entomology, 63(3), 211- 214.

Samadia DK \& Haldhar SM. 2017. Breeding strategies and scope of improvement in arid zone fruit crop-plants under abiotic stressed agro-climate: an analysis. Journal of Agriculture and Ecology, 4: 1-13.

Satyanarayana C \& Arunakumara KT. 2016. Biology and management of guava bark eating caterpillar (Indarbela tetraonis Moore). Agriculture Science Digest, 36 (3): 197-201.

Sen-Sharma PK. 1987. Insect problems in social forestry plantation. Indian-Journal of Forestry, 10 (4); 239-244.

Sharaf NS. 1997. Host plants and natural enemies of mealybugs and other related Homopterans, with special reference to the spherical mealybug, Nipaecoccus viridis (Newstead), in Jordan. Dirasat Agricultural Sciences, 24: 383-390.

Sharaf NS \& Meyerdrik DE. 1987. A review on the biology, ecology and control of Nipaecoccus $\quad$ viridis (Homoptera: Pseudococcidae). Miscellaneous

Publication of the Entomological Society of America, 66: 1-18.

Singh G. 1993. Insect pest of other subtropical fruits. Advances-in horticulture fruit crop, 3: 1501-1526. 